QUALITY MANAGEMENT PURCHASING AND ITS EFFECT ON PURCHASING'S OPERATIONAL PERFORMANCE AND INTERNAL CUSTOMER SATISFACTION

This study was carried out in Spain 


\author{
Cristóbal Sánchez-Rodríguez \\ School of Business \& Economics \\ Wilfrid Laurier University \\ Waterloo, Ontario N2L 3C5, Canada \\ csanchez@wlu.ca
}

David Hemsworth (corresponding author)

School of Business \& Economics

Wilfrid Laurier University

Waterloo, Ontario N2L 3C5, Canada

david@hemsworth.ca

Phone (519) 884-0710 x 2884

Fax (519) 884-0201

\author{
Ángel R. Martínez-Lorente \\ Departamento de Economía de la Empresa \\ Universidad Politécnica de Cartagena \\ Avda Alfonso XIII \\ angel.martinez@upct.es
}

Acknowledgment: The authors wish to thank Cajamurcia (Spain) for its financial support of this research. 


\begin{abstract}
Supply chain management (SCM) and total quality management (TQM) can help provide organizations with a sustainable competitive advantage by improving product quality and service while reducing cost. An effective purchasing function is one of the essential competencies to supply chain success and quality management. The objective of this research was to empirically examine a mediational model in which quality management purchasing has a direct impact on purchasing's internal customer satisfaction and an indirect impact mediated through purchasing's operational performance. All measurement scales satisfy key measurement criteria including unidimensionality, convergent validity, discriminant validity, and reliability. Our study showed that quality management purchasing is significantly related to purchasing's operational performance and internal customer satisfaction.
\end{abstract}




\section{QUALITY MANAGEMENT PURCHASING AND ITS EFFECT ON PURCHASING'S OPERATIONAL PERFOMRANCE AND INTERNAL CUSTOMER SATISFACTION}

\section{Introduction}

In an increasingly complex business environment, today's firms are continuously looking for new ways to remain competitive. Supply chain management (SCM) can help provide a sustainable competitive advantage by improving product performance and service while simultaneously reducing cost (Davis, 1993).

It has been argued that the scope of SCM goes beyond the concept of integrated logistics and combines all business processes (Cooper et al., 1997), including quality management (Romano \& Vinelli, 2001). Recent literature supports this view and a number of papers have been published analyzing the role of quality management in SCM (e.g., Fynes \& Voss, 2002; Kuei et al., 2001; Romano \& Vinelli, 2001; Salvador et al., 2001; Tan et al., 1999) and logistics (e.g., Anderson et al., 1998; Millen et al., 1999; Tracey, 1998).

An effective purchasing function has also been considered a key business process in the supply chain (Fawcett \& Fawcett, 1995; Giunipero \& Brand, 1996; Lambert et al., 1998). In this respect, purchasing's role in SCM is very important as an intermediary in the supply chain, connecting suppliers with purchasing's internal customers who, in turn, provide products and services for external customers (Stanley \& Wisner, 2001).

Despite the importance of purchasing and quality management to supply chain success, there has been relatively little research to date regarding quality management purchasing and its effect on purchasing's operational performance and internal customer satisfaction. Consequently, the 
purpose of this research was to develop a framework that relates quality management purchasing with purchasing's operational performance and internal customer satisfaction. More specifically, the objectives of this paper were to determine (1) if the implementation of quality-management purchasing had a positive impact on purchasing's operational performance, and (2) on purchasing's internal customer satisfaction. To meet these objectives, we reviewed the relevant literature and developed and tested hypotheses by means of structural equations modeling. The findings extend our understanding of quality management purchasing and its contribution to supply chain performance.

\section{Literature review}

The critical role of the purchasing function in quality management was first stressed in the early works of the acclaimed "quality gurus" (Deming, 1982; Juran, 1989; Ishikawa, 1985). Based on their work, more recent theory in total quality management (TQM) has acknowledged this critical role by considering the type of buyer-supplier relationship a key element of TQM (Saraph et al., 1989; Anderson et al., 1994; Flynn et al., 1994; Powell, 1995; Ahire et al., 1996; Black \& Porter, 1996).

Using the supplier as the unit of analysis, a number of papers have investigated the nature of buyer-supplier relationships in a TQM environment. These studies discuss the practices involved with this type of relationship (Lascelles \& Dale, 1989; Giunipero \& Brewer, 1993; Stuart \& Mueller, 1994; Trent \& Monczka, 1999), the barriers that could hinder their implementation (Lascelles \& Dale, 1989), and their effect on performance (Brookshaw \& Terziovski, 1997; Carter \& Miller, 1989; Forker, 1997; Kekre et al. 1995; Lascelles \& Dale, 1989; Stuart \& Mueller, 1994).

In contrast, a relatively small number of papers have used the purchasing function as the unit of analysis to study the implications of TQM in purchasing. For example, Carter and Narasimhan 
(1994) analyzed the purchasing function in a TQM environment and found evidence of the interaction between purchasing and manufacturing in quality improvement, purchasing personnel autonomy, use of supplier improvement, supplier qualification, and supplier certification. In a later work, using the same survey data, Carter and colleagues (1998) developed a instrument to measure TQM in purchasing and identified seven distinctive factors, namely: importance of the purchasing function, interaction with suppliers, interaction with other functional areas, human resources management, influence over suppliers, competitive focus, and structure and organization of purchasing. However, there are some concerns about the reliability and content validity of the instrument they developed since some of the factors included indicators that did not represent the factor they were intended to measure.

Caddick and Dale (1998) collected case study data and analyzed the influence of TQM on four areas in the purchasing function finding no evidence of a revised role of purchasing in a TQM environment. However, the findings of the research suffer from a lack of generalizability since the authors reported empirical evidence from only a single case study. More recently, Hemsworth and Sánchez-Rodríguez (2003) developed and tested an underlying framework to measure the influence of quality management on purchasing performance and internal customer satisfaction.

In summary, it appears from the literature that there is an agreement about the key role that purchasing can play in assuring the quality of a product. Despite a few exceptions, most research has used the supplier as the unit of analysis, overlooking the role played by other elements in the purchasing function. Furthermore, we are unaware of any empirical work that has expressly tested the relationship among quality management purchasing, purchasing's operational performance, and purchasing's internal customer satisfaction. In the following section of our paper, we therefore introduce a theoretical model exploring this phenomenon and the hypotheses to be tested. 
Theoretical Framework and Hypotheses

There are three relationships portrayed in our theoretical model shown in Figure 1. There is generally consistent support in the literature for a positive relationship between quality management and the overall company's operational performance and customer satisfaction (e.g., Anderson et al., 1994; Choi \& Eboch, 1998; Curkovic et al., 2000; Dean \& Bowen, 1994). Therefore, it would be reasonable to assume that the implementation of quality management purchasing would be related to purchasing's operational performance and internal customer satisfaction. Each of the constructs is discussed below.

$<$ Take in Figure 1 $>$

\section{Quality management purchasing}

A TQM strategy is aimed at reducing quality problems and increasing customer satisfaction. According to the literature, the basic elements of a TQM strategy would include the following: top management support, personnel management, process management, customer relationships, supplier relationships, quality information, product design, and benchmarking (see, for example, Ahire et al., 1996; Anderson et al., 1994; Black \& Porter, 1996; Flynn et al., 1994; Powell, 1995; Saraph et al., 1989).

Based on these TQM basic elements and using the purchasing function as the unit of analysis, a similar set of key elements could be developed to define quality management purchasing. Therefore, we have used the six following salient factors or constructs to define quality management purchasing: supplier quality management, personnel management, cross-functional coordination, quality information, management commitment, and benchmarking (see Figure 2). No equivalent quality management purchasing element was developed for "process management" since it refers to the use of statistical process control to manage the quality in the manufacturing 
process (Ahire et al., 1996; Anderson et al., 1994; Black \& Porter, 1996; Flynn et al., 1994; Saraph et al., 1989). Cross-functional design, which describes the interaction of purchasing with internal customer departments and purchasing's involvement in the firm's new product development process, incorporates elements of "customer relationships" and "product design."

A brief description of each construct, along with selected literature that supports and describes them, is presented in Table I. In addition, the items used to operationalize each construct are shown in the Appendix.

$<$ Take in Table I $>$

Operational Performance

This construct was based on Chao and others' (1993) objective criteria for evaluating purchasing performance, which is operationalized by measuring the quality of purchased items, on-time delivery, actual versus target cost, process order cycle time, and accuracy. The process order cycle time (i.e., average time from the receipt of the requisition until the purchase order is sent to a supplier) and accuracy criteria (number of errors made by purchasing in such areas as specifications, quantity, price, due date, etc.) were not included in this construct since they were incorporated in the internal customer satisfaction construct under the "reliability" and "responsiveness" elements. In contrast, we decided to include an indicator referred to as materials inventory performance since it is a common assessment area for purchasing performance (Leenders et al., 2002). Therefore, the operational performance construct included measures of the quality of purchased items, on-time delivery, actual versus target cost of materials, and level of achievement of inventory goals (see the Appendix for measurement indicators). 
Internal Customer Satisfaction

Several studies in the literature have used the concept of service quality to evaluate internal customer satisfaction levels (Stanley \& Wisner, 1998; 2001; 2002; Young \& Varble, 1997). For the purchasing function, the customers are the company department for whom the material or service is purchased and thus are defined as internal customers. A widely used instrument to measure customer satisfaction has been the SERVQUAL questionnaire developed by Parasuraman et al. $(1985 ; 1988)$. Using that tool, we operationalized customer satisfaction following the set of service quality dimensions identified by Parasuraman et al. $(1985 ; 1988)$, namely: reliability (the ability of the purchasing department to perform the promised service dependably and accurately); responsiveness (the willingness of the purchasing department to help internal customers and provide prompt service); assurance (the knowledge and courtesy of purchasing department's employees and their ability to convey trust and confidence); empathy (the caring, individualized attention the purchasing department provides to customers); and tangibles (the appearance of the purchasing department's physical facilities, equipment, personnel, and communication material). The purchasing's internal customer satisfaction construct was measured accordingly and the measurement indicators used are listed in the Appendix. Although some authors have argued that performance-based measures are more effective for evaluating service quality than SERVQUAL (e.g., Cronin \& Taylor, 1994; Teas 1994), the SERQUAL model was chosen as the measurement tool for this investigation because it is a widely used research instrument that provides the breadth and accuracy to capture the complexities of the internal customer satisfaction construct. Future research could attempt to compare and contrast these two models incorporating performance-based measures into the operationalization of this construct. 


\section{Hypotheses}

It has been found that the implementation of supplier quality management lowers materials costs, increases quality of materials, reduces delays in deliveries from suppliers, and eliminates mistakes in quantities ordered and received (Anderson et al., 1995; Lamming, 1993; Noordewier et al., 1990; Vonderembse \& Tracey, 1999; Watts \& Hahn, 1993). However, the successful implementation of supplier quality management is preceded by the existence of an effective quality information system (Krause, 1999; Lascelles \& Dale, 1989). The literature has also suggested that the ability of the purchasing function to provide the optimum service to their internal customers is influenced by supplier's performance levels (Stanley \& Wisner, 2001; Wisner \& Stanley, 1999).

Additionally, empirical research in TQM has shown that cross-functional coordination and management commitment are positively correlated with quality performance and service quality (Curkovic et al., 2000), and that company performance is positively correlated with personnel management (Carter et al., 2000) and benchmarking (Carr \& Smeltzer, 1999). Therefore, and according to previous evidence from the literature, the adoption of quality management purchasing is expected to directly increase purchasing's operational performance and internal customer satisfaction. However, the effect of quality management purchasing on internal customer satisfaction could also be indirect through operational performance, which is an intermediate performance outcome. Thus, the following hypotheses were formulated:

H1: the implementation of quality management purchasing has a positive impact on purchasing's operational performance 
$\mathrm{H} 2$ : the implementation of quality management purchasing has a positive impact on purchasing's internal customer satisfaction, either directly or indirectly, through operational performance, or both (see Figure 1).

\section{Research Methodology}

\section{Sample description}

The sample frame consisted of 1,200 purchasing managers who were selected from the Duns and Bradstreet database of the largest manufacturing companies in Spain. Purchasing managers were determined as the most appropriate respondents, because they are most familiar with their organization's purchasing practices and performance outcomes.

A modified version of Dillman's Total Design Method (1978) for survey research was used to ensure the highest possible response rate. A cover letter explaining the purpose of the study and a survey questionnaire, along with a postage-paid envelope, were sent to all members in the sample frame. A letter encouraging non-respondents to participate in the research was sent three weeks later. Six weeks after the initial mailing, a second survey and cover letter were sent to the remaining non-respondents. Of the 1,200 surveys mailed, eight were returned undeliverable. Three hundred and six usable responses were received, which translates into a 25 percent response rate. The respondent sample was composed of high-level purchasing executives, including 145 directors of purchasing (48\%), 89 general managers of purchasing (29\%), 19 purchasing managers (6\%), and 45 “other" titles (17\%).

Two approaches were used to assess non-response bias. The first approach consisted of comparing early with late respondents following Armstrong and Overton's (1977) recommendations. No significant differences were found between early and late respondents on all variables, which included sales volume, number of employees, and cost of raw materials and 
components. The second approach involved a comparison of sales revenue and number of employees between responding firms and non-responding firms (see Table II). This comparison was done by controlling the name of the companies that completed the survey and adding this information to the Duns and Brandstreet database. Because no significant differences were found between the two sample groups, the respondent's sample was considered representative of the targeted industries.

Respondents reported an average of 779 employees; a total of 50 percent of the companies employed between 101 and 500 employees (155 firms). The largest firm employed 15,000 workers and also had the highest annual sales ( $€ 5.4$ billion). A diverse group of manufacturing organizations participated in the study. In descending order of response frequency, food, automotive components, miscellaneous manufacturing, and chemicals were the most widely represented industries in the respondent group (see Table III). Annual gross sales for the year 2000 of the companies surveyed ranged from 34 million Euros $(€)$ to $€ 5.4$ billion, with an average annual sales of $€ 141$ million.

$<$ Take in Table II $>$

$<$ Take in Table III $>$

\section{Scale development}

A four-page survey instrument incorporating a list of quality management purchasing activities was developed based on the literature reviewed. Operations management faculty were used as expert judges for content validation to determine how well the chosen items represented the defined constructs. Purchasing managers at five manufacturing sites were interviewed, while they reviewed the questionnaire, to identify any language ambiguities and perceived omissions of 
other relevant practices not included in the survey. The discrepancies and comments were used to further refine the instrument.

The survey instrument measured a total of 34 items: 25 items referred to quality management purchasing practices, 4 items related to purchasing's operational performance, and 5 items related to purchasing's internal customer satisfaction (see Table IV). In order to measure those items, respondents were asked to indicate the degree of agreement or disagreement with the statements listed in the Appendix, using five-point Likert scales, where 1 represented "strongly disagree" and 5 represented "strongly agree." For example, for item V6 in Table IV (pertaining to supplier's sharing of internal information), the question in the survey instrument was: "Purchasing has access to suppliers' internal information (e.g., production costs, level of quality, etc.).”

$<$ Take in Table IV $>$

\section{Results}

\section{Construct validation}

A series of confirmatory factor analyses (CFA) were conducted to address the validity and reliability of the constructs in our study (Anderson \& Gerbing, 1988). The construct structure could not be individually confirmed for cross-functional coordination, quality information, management commitment, and benchmarking because the measurement models would be just identified with three items only (degrees of freedom, d.f. $=0$ ). Therefore, a two-construct structure was estimated. That is, management commitment and benchmarking were confirmed together as a pair, and similarly, so were cross-functional coordination and quality information. In order to test the composite construct of quality management purchasing, we averaged the scores for the supplier quality management (SQM), personnel management (PM), cross-functional 
coordination (CFC), quality information (QI), management commitment (MC), and benchmarking (BK). For example, the mean of the responses from manifest variables V1 to V7 was computed to determine the composite measure for supplier quality management (SQM).

Multiple fit criteria were used to assess the appropriateness of the measurement models tested (Bollen \& Long, 1993; Hair et al., 1995). The recommended threshold values are shown in Table $\mathrm{V}$, indicating that the models had a reasonably good fit.

Convergent validity is demonstrated when a set of alternative measures accurately represents the construct of interest (Churchill, 1979). For this study, convergent validity was assessed reviewing the level of significance for the factor loadings. If all the individual item factor loadings are significant, then the indicators are effectively measuring the same construct (Anderson \& Gerbing, 1988). The coefficients for all indicators in the six quality management constructs were large and significant ( $t$-values $>2.576 ; p<0.01)$, which provides strong evidence of convergent validity. Similarly, the coefficients for the indicators in the constructs of quality management purchasing and operational performance were also high and strongly significant ( $t$-values $>2.576$; $p<0.01)$. The internal customer satisfaction construct also showed sufficient evidence of convergent validity after one indicator (tangibles) was eliminated due to lack of statistical significance.

\section{$<$ Take in Table V}

Discriminant validity among the latent variables and their associated measurement variables can be assessed by fixing (i.e., constraining) the correlation between pairs of constructs to 1.0, then re-estimating the modified model (Segars \& Grover, 1993). By fixing the correlation between the two constructs to 1.0, we convert a two-construct model into a single-construct model. The condition of discriminant validity is met if the difference of the chi-square statistics between the constrained and standard models is significant (1 D.F.). The chi-square difference tests indicate 
that discriminant validity exists among all constructs conforming quality management purchasing (supplier quality management, personnel management, cross-functional coordination, quality information, management commitment, and benchmarking) $(p<0.01)$ (see Table VI). Discriminant validity also exists among the quality management purchasing, operational performance, and internal customer satisfaction constructs (see Table VI).

Scale reliability provides a measure of the internal consistency and homogeneity of the items comprising a scale (Churchill, 1979) and it was calculated as follows (Hair et al., 1995):

$$
\frac{{\text { (summation of factor loadings })^{2}}^{2}}{\text { (summation of factor loadings })^{2}+(\text { summation of error variances) }}
$$

All constructs displayed composite reliabilities in excess of 0.70 except for cross-functional coordination, operational performance, and internal customer satisfaction, which were above the recommended minimum of 0.60 for exploratory studies (Churchill, 1979). Thus, these results provide supporting evidence that the scales used in this study are reliable.

$<$ Take in Table VI $>$

\section{Hypothesis testing and discussion}

The hypotheses presented in the "hypotheses" subsection were tested using structural equation modeling (SEM). SEM is an appropriate statistical technique when assessing the relationships among latent constructs that are measured by multiple scale items, where at least one construct is both a dependent and an independent variable (Hair et al., 1995). Additionally, it allows researchers to estimate the strength of relationships among scale items and latent constructs, as well as giving the investigator an indication of overall model fit. As recommended by many researchers, multiple fit criteria were assessed to rule out measuring biases inherent in the various measures (Bollen \& Long, 1993; Hair et al., 1995). For these reasons, we tested the study's 
hypotheses using structural equation modeling. Our theoretical model in LISREL notation is presented in Figure 2.

$<$ Take in Figure 2>

The chi-square statistic was significant $\left(\chi^{2}=123.35\right.$; d.f. $\left.=74 ; \mathrm{p}<0.05\right)$. However, the chi-square estimate has been shown to be over-sensitive to small model discrepancies when sample sizes are larger than 200, or when the model contains a large number of variables (i.e., the model is complex) (Bagozzi \& Yi, 1988; Byrne, 1994; Hair et al., 1995). When this is the case, alternative methods of fit must be also taken into consideration. When the other indices were examined, they indicated a good fit between the data and the model. The ratio $\chi^{2} /$ d.f. and RMS with values of 1.67 and 0.052 respectively, were below the recommended maximum of 3.00 and 0.10 (Chau, 1997). Similarly, the index RMSEA was below the 0.10 minimum acceptable level, with a value of 0.047. Additionally, the indexes NNFI, CFI, GFI, and AGFI were all above the minimum acceptable 0.90 level, with values of $0.93,0.94,0.95$, and 0.92 , respectively. The results of the structural model estimation are shown in Figure 3. Researchers sometimes free additional paths (potentially, based on modification indices) such as correlations between error variances, with the only purpose to improve the fit of the model to the data (Jöreskog \& Sörbom, 1993). In many cases, these alterations to the model are difficult to justify theoretically and frequently not reported. Since our model provided strong evidence of adequate fit, these modifications were not undertaken and all error variances were left uncorrelated and all estimated paths are shown in Figure 2.

The test of the proposed hypotheses is based on the direct and indirect effects in the structural model. Path coefficients between latent variables (constructs) give an indication of the relative strength of each relationship (Jöreskog \& Sörbom, 1993). Both hypotheses were tested at the significance level $p<0.05$, two-tailed. 
The first hypothesis asserts that the implementation of quality management purchasing has a positive impact on purchasing's operational performance. According to the results shown in Figure 3 , the path relating these two constructs was positive and significant (standardized $\gamma_{1}$ coefficient $=0.46 ; t$-value $=6.06 ; p<0.01$ ), thus providing strong evidence supporting hypothesis 1 . This indicates that the adoption of quality management practices in purchasing increases the level of purchasing's operational performance.

The second hypothesis states that the implementation of quality management purchasing has a positive influence on purchasing's internal customer satisfaction. This hypothesis was tested by evaluating the direct and indirect effects of quality management purchasing on internal customer satisfaction. According to the results shown in Figure 3, the direct path relating quality management purchasing and internal customer satisfaction was positive and significant (standardized $\gamma_{2}$ coefficient $=0.19 ; t$-value $=2.47 ; p<0.01$ ), thus providing strong evidence of the direct effect of quality management purchasing on internal customer satisfaction and partially confirming hypothesis 2. Similarly, the path relating operational performance and internal customer satisfaction was positive and significant $\left(\right.$ standardized $\beta_{1}$ coefficient $=0.64 ; t$-value $=$ 6.84; $p<0.01$ ) which, combined with the significant direct effect of quality management on operational performance (standardized $\gamma_{1}$ coefficient $=0.46 ; t$-value $=6.06 ; p<0.01$ ), results in the existence of a positive and significant indirect effect of quality management purchasing on internal customer satisfaction $\left(\gamma_{1} \bullet \beta_{1}=0.30 ; t\right.$-value $\left.=4.88 ; p<0.01\right)$. These results provide strong support for hypothesis two and indicate that the adoption of quality management purchasing has a positive direct impact on purchasing's internal customer satisfaction, and a indirect positive impact mediated through purchasing's operational performance.

$<$ Take in Figure 3 $>$ 


\section{Conclusions and Managerial Implications}

This study is the first empirical research to test the relationship between quality management purchasing, purchasing's operational performance, and internal customer satisfaction using structural equation modeling.

In the process of addressing the research hypotheses, valid and reliable instruments were developed to measure the key constructs of the study, namely quality management purchasing, operational performance, and internal customer satisfaction. The measurement instruments were tested for convergent and discriminant validity, and the results showed that the multiple-item scales developed were valid and highly reliable for the manufacturing industry sample.

The research provides strong support for the hypotheses explored in this paper. An important finding was that the extent of adoption of quality management purchasing has a direct positive impact on the operational performance of the purchasing function. Therefore, it could be concluded that the implementation of a quality management purchasing initiative (supplier quality management, personnel management, cross-functional coordination, quality information, management commitment, and benchmarking) will contribute to improving purchasing's operational performance (i.e., increasing quality of materials purchased, ensuring on-time delivery from suppliers, meeting material expending targets, and achieving inventory goals). Additionally, the implementation of quality management purchasing was found to directly improve purchasing's internal customers satisfaction levels, as well as indirectly through better levels of purchasing's operational performance.

Supply chain managers could benefit from this research in several ways. First, it provides them with a better understanding of what practices define quality management purchasing. The results suggest that quality management purchasing is brought about by implementing supplier quality management, personnel management, cross-functional coordination, quality information, 
management commitment, and benchmarking. Second, it provides supply chain managers with a set of practices that can be used to improve purchasing's operational performance and internal customer satisfaction. Third, by providing evidence that quality management purchasing has a positive impact on purchasing's operational performance and internal customer satisfaction, supply chain managers can effectively justify the contribution of quality management purchasing to supply chain performance and demand more attention from top management.

This study exposes a number of opportunities and areas for future research. The use of a single key informant could be seen as a potential limitation of the study, and this study's findings should be confirmed in the future using information directly obtained from actual suppliers and internal customers. Our study was a cross-sectional and descriptive sample of the manufacturing industry at a given point of time. A more stringent test of the relationships between quality management practices and performance requires a longitudinal study, or field experiment, which could gather information about quality management practices and performance on an appropriate time span. Then the association between the variation of independent factors and the variation of performance could be further investigated. Future research could also expand the model in this study by including additional factors, such as the introduction of information technologies in the purchasing department.

\section{Appendix}

On a scale of $1=$ strongly disagree to $5=$ strongly agree, indicate your firm's position on each of the following indicators:

\section{A.1. Quality management purchasing}

\section{A.1.1. Supplier quality management}

V1 Suppliers are certified ISO 9000. 
V2 We visit suppliers' factories to assess their facilities.

V3 Suppliers are recognized and rewarded for materials' quality improvement.

V4 The company provides training to its suppliers.

V5 We maintain relationships with a limited number of suppliers (3 or less for every purchased material).

V6 Purchasing has access to suppliers' internal information (production costs, level of quality, etc.).

V7 Suppliers participate in the company's new product development process.

\section{A.1.2. Personnel management}

V8 Purchasing employees enjoy a high degree of autonomy in their decisions.

V9 Purchasing employees perceive a high degree of security in their job.

V10 Purchasing employees participate in the solution of problems through suggestions, opinions, etc.

V11 There is a high emphasis on training for purchasing employees.

V12 Purchasing employees participate in supplier selection teams.

V13 The procedure for personnel reward and recognition is based on teamwork performance.

\section{A.1.3. Cross-functional coordination}

V14 Purchasing participates with Quality and/or Production in determining the specifications.

V15 Purchasing collaborates with Production/Manufacturing in solving production problems.

V16 Purchasing participates in the new product development process.

\section{A.1.4. Quality information}

V17 We collect information (data) about quality performance (supplier's reject rate, degree of internal customer satisfaction, etc.).

V18 Purchasing is informed of quality performance evaluations. 
V19 Suppliers are informed about their level of performance (quality, delivery, cost, etc.).

\section{A.1.5. Management commitment}

V20 Purchasing management communicates to purchasing employees that quality is the most important purchasing objective.

V21 Purchasing management is evaluated based on quality performance (materials purchased defects rate, degree of internal customer satisfaction, etc.).

V22 Quality is the most important criteria in the selection and evaluation of suppliers.

\section{A.1.6. Benchmarking}

V23 We search for info about prices and level of quality of purchases of other companies in our industry.

V24 We analyze the purchasing process of other companies to improve our own purchasing process.

V25 There is a formal procedure to compare our purchasing performance with the purchasing performance of other companies.

\section{A.2. Operational Performance}

V26 Most raw materials and parts received are in conformance with specifications.

V27 All raw materials and parts arrive within the delivery date.

V28 The quantity of materials purchased in inventory meets the company's quantity performance objective.

V29 The materials' target cost (standard cost or budgeted cost) is met.

\section{A.3. Internal Customer Satisfaction}


V30 We have received complaints from our customer departments because of our incapacity to provide the service promised $(\mathrm{R})$.

V31 We have not received complaints from our customer departments because of deficiencies in the knowledge or courtesy of the purchasing staff.

V32 Customer departments are satisfied with the speed with which we react to their requirements.

V33 Customer departments are satisfied with the attention and dedication that purchasing show for their problems.

* (Tangibles) We have not received complaints from our customer departments because of the situation of our facilities, furniture, personnel appearance, etc. (R).

* item dropped during validity and reliability analysis.

$\mathrm{R}=$ reverse coded

\section{References}

Ahire, S.L., Golhar, D., \& WAller, M.A. (1996) Development and validation of TQM implementation constructs, Decision Sciences, 27, (1), pp. 23-56.

ANDERSON, J.C \& GERBING, D.W. (1988) Structural equation modelling in practice: a review and recommended two-step approach, Psychological Bulletin, 103, (2), pp. 411-423.

Anderson, J.C., Rungtusanatham, M. \& Schroeder, R.G., (1994) A theory of quality management underlying the Deming management method, Academy of Management Review, 19, (3), pp. 472-509.

Anderson, J.C., Rungtusanatham, M., Schroeder, R.G., \& Devaraj, S. (1995) A path analytic model of a theory of quality management underlying the Deming management method: preliminary empirical findings. Decision Sciences, 26, (5), pp. 637-658. 
ANDERSON, R.D., JERMAN, R.E. \& CRUM, M.R. (1998) Quality management influences on logistics performance, Transportation Research E: Logistics and Transportation Review, 34, (2), pp. 137-148.

ARMSTRONG, J.S. \& OVERTON, T.S. (1977) Estimating nonresponse bias in mail surveys, Journal of Marketing Research, 14, (3), pp. 396-402.

BAGOZZI, R.P. \& YI, Y. (1988) On the evaluation of structural equation models, Academy of Marketing Science, 6, (1), pp. 74-93.

BENSON, P.G., SARAPH, J.V. \& SCHROEDER, R.G. (1991) The effects of organizational context on quality management: an empirical investigation, Management Science, 37, (9), pp. $1107-1124$.

BLACK, S.A. \& PORTER, L.J. (1996) Identification of the critical factors of TQM, Decision Sciences, 27, (1), pp. 1-21.

Bollen, K.A. \& Long, J.S. (1993) Testing Structural Equation Models (Newbury Park, CA: Sage Publications).

BRoOKshaw, T. \& TERZIOVSKI, M. (1997) The relationship between strategic purchasing and customer satisfaction within a total quality management environment, Benchmarking for Quality Management and Technology, 4, (4), pp. 244-258.

BURT, D.N. (1989) Managing product quality through strategic purchasing, Sloan Management Review, 30, (3), pp. 39-48.

BYRNE, B.M. (1994) Structural Equation Modelling with EQS and EQS/Windows: Basic Concepts, Applications, and Programming (Thousand Oaks, CA., Sage Publications).

CADDICK, R.J. \& DALE, B.G. (1998) The impact of total quality management on the purchasing function: influences and implications, European Journal of Purchasing and Supply Management, 4, (2-3), 133-142.

CAMP, R.C. (1989) Benchmarking: The Search for Industry Best Practices that Lead to Superior Performance (Milwaukee, WI., ASQC Press). 
CARR, A.S. \& SMELTZER, L.R. (1999) The relationship among purchasing benchmarking, strategic purchasing, firm performance, and firm size, The Journal of Supply Chain Management, fall, pp. 51-60.

CARTER, J.R. \& MiLleR, J.G. (1989) The impact of alternative vendor/buyer communication structures on the quality of purchased materials, Decision Sciences, 20, (4), pp. 759-776.

CARTER, J.R. \& NARASIMHAN, R. (1994) The role of purchasing and materials management in total quality management and customer satisfaction, International Journal of Purchasing and Materials Management, 30, (3), pp. 2-13.

Carter, J.R., Smeltzer, L. \& NArasimhan, R. (1998) The role of buyer and supplier relationships in integrating TQM through the supply chain, European Journal of Purchasing and Supply Management, 4, (4), pp. 223-234.

CARTER, J.R., SMeltzer, L. \& NARAsimhan, R. (2000) Human resource management within purchasing management: its relationship to Total Quality Management success, The Journal of Supply Chain Management, 36, (2), pp. 52-62.

COOPER, M.C., LAMBERT, D.M. \& PAGH, J.D. (1997) Supply chain management: more than a new name for logistics, International Journal of Logistics Management, 8, (1), 1-13.

Chao, C., Scheuing, E.E. \& Ruch, W.A. (1993) Purchasing performance evaluation: an investigation of different perspectives, International Journal of Purchasing and Materials Management, 29, (3), pp. 33-39.

CHAU, P.Y.K. (1997) Reexamining a model for evaluating information center success using a structural equation modelling approach, Decision Sciences, 28, (2), pp. 309-334.

CHOI, T.Y. \& EBOCH, K. (1998) The TQM paradox: relations among TQM practices, plant performance, and customer satisfaction, Journal of Operations Management, 17, (1), pp. $59-75$.

CHURCHILL, G.A. JR. (1979) A paradigm for developing better measures of marketing constructs, Journal of Marketing Research, 16, (1), pp. 64-73. 
CRONIN, J.J. JR. \& TAYLOR, S.A. (1994) SERVPERF versus SERVQUAL: reconciling performance-based and perceptions-minus-expectations measurement of service quality, Journal of Marketing, 58, (1), pp. 125-131.

Curkovic, S., Vickery, S. \& Droge, C. (2000) Quality-related elements: their impact on quality performance and firm performance, Decision Sciences, 31, (4), pp. 885-905.

DALE, B.G. (1999) Managing quality (Oxford, Herts, Blackwell Publishers)

DAVIS, T. (1993) Effective supply chain management, Sloan Management Review, Summer, pp. $35-46$.

DEAN, J.W. JR. \& BOWEN, D.E. (1994) Management theory and total quality: improving research and practice through theory development, Academy of Management Review, 19, (3), pp. $392-418$.

Deming, W.E. (1982) Quality, Productivity, and Competitive Position (Cambridge, Massachusetts Institute of Technology).

Dillman, D.A. (1978) Mail and Telephone Surveys: The Total Design Method (New York, John Wiley).

DOWLATSHAHI, S. (1998) Implementing early supplier involvement: a conceptual framework, International Journal of Operations and Production Management, 18, (2), pp. 143-167.

FAWCETT, S.E. \& FAWCETT, S.A. (1995) The firm as a value-added system: integrating logistics, operations and purchasing, International Journal of Physical Distribution and Logistics Management, 25, 5, pp. 24-42.

FLynN, B.B., SAKAKIBARA, S. \& SCHROEDER, R.G. (1994) A framework for quality management research and an associated measurement instrument, Journal of Operations Management, 11, (4), pp. 339-366.

FORKER, L.B. (1997) Factors affecting supplier quality performance, Journal of Operations Management, 15, (4), pp. 243-269.

FYNES, B. \& VOSS, C. (2002) The moderating effect of buyer-supplier relationships on quality practices and performance, International Journal of Operations and Production Management, 22, (6), pp. 589-613. 
GIUNIPERO, L.C. \& BRAND, R.R. (1996) Purchasing's role in supply chain management, International Journal of Logistics Management, 7, (1), pp. 29-38.

GiuniPero, L.C. \& BREWER, D.J. (1993) Performance based evaluation systems under Total Quality Management, International Journal of Purchasing and Materials Management, 29, (1), pp. 35-41.

GIUNIPERO, L.C. \& VoGT, J.F. (1997) Empowering the purchasing function: moving to team decisions, International Journal of Purchasing and Materials Management, 33, (1), pp. $8-15$.

Hemsworth, D. \& SAnchez-Rodriguez, C. (2003) The effect of quality management on purchasing's performance and internal customer satisfaction; a structural model, Administrative Sciences Association of Canada (ASAC) Conference Proceedings.

Hair, J.F. JR., Anderson, R.E., TATHAM, R.L. \& BlACK, W.C. (1995) Multivariate Data Analysis with Readings (Englewood Cliffs, NJ, Prentice Hall).

ISHIKAWA, K. (1985) What is Total Quality Control? The Japanese Way (London, Prentice Hall).

JÖRESKOG, K.G. \& SÖRBOM, D. (1993) LISREL 8: Structural Equation Modelling with the SIMPLIS Command Language (Chicago, IL, Scientific Software International).

JURAN, J.M. (1989) Juran on Leadership for Quality (New York, Free Press).

KEKRE, S., MURTHI, B.P.S. \& SRINIVASAN, S. (1995) Operating decisions, supplier availability and quality: an empirical study, Journal of Operations Management, 12, (3-4), pp. 387396.

KRAUSE, D.R. (1999) The antecedents of buying firms' efforts to improve suppliers, Journal of Operations Management, 17, (2), pp. 205-224.

KUEI, C., MADU, C. \& LIN, C. (2001) The relationship between supply chain quality management practices and organizational performance, International Journal of Quality and Reliability Management, 18, (8), pp. 864-872.

LAMBERT, D.M., COOPER, M.C. \& PAGH, J.D. (1998) Supply chain management: implementation issues and research opportunities, International Journal of Logistics Management, 8, (1), pp. 1-19. 
LAMMING, R. (1993) Beyond Partnership: Strategies for Innovation and Lean supply (London, Prentice-Hall).

LASCElles, D.M. \& DAlE, B.G. (1989) The buyer-supplier relationship in total quality management, Journal of Purchasing and Materials Management, 25, (2), pp. 10-19.

LeEnders M.R., FeAron H.E., Flynn A.E., \& Johnson P.F. (2002) Purchasing and supply management (Chicago, IL., McGraw-Hill Irwin).

Millen, R., SoHAL, A. \& Moss, S. (1999) Quality management in the logistics function: an empirical study, International Journal of Quality and Reliability Management, 16, (2), pp. 166-180.

Noordewier, T., George, J. \& Nevin, J. (1990) Performance outcomes of purchasing arrangements in industrial buyer-vendor relationships, Journal of Marketing, 54, (4), pp. $80-93$.

Parasuraman, A., Zeithaml, V.A. \& Berry, L.L. (1985) A conceptual model of service quality and its implications for future research, Journal of Marketing, 49, (4), pp. 41-50.

PARASURAmAn, A., ZeITHAML, V.A. \& BERry, L.L. (1988) SERVQUAL: a multiple-item scale for measuring consumer perceptions of service quality, Journal of Retailing, 64, (1), pp. $12-40$.

POWELL, T.C. (1995) Total quality management as competitive advantage: a review and empirical study, Strategic Management Journal, 16, (1), pp. 15-37.

Romano, P. \& Vinelli, A. (2001) Quality management in a supply chain perspective, International Journal of Operations and Production Management, 21, (4), pp. 446-460.

Salvador, F., Forza, C., Rungtusanatham, M. \& Choi, T.Y. (2001) Supply chain interactions and time-related performances, International Journal of Operations and Production Management, 21, (4), pp. 461-475.

SARAPH, J.V., Benson, P.B., \& Schroeder, R.G. (1989) An instrument for measuring the critical factors of quality management, Decision Sciences, 20, (4), pp. 810-829.

Segars, A.H. \& Grover, V. (1993) Re-examining perceived ease of use and usefulness: A confirmatory factor analysis, MIS Quarterly, 17, (4), pp. 517-525. 
STANLEY, L.L. \& WISNER, J.D. (1998) Internal service quality in purchasing: an empirical study, International Journal of Purchasing and Materials Management, 34, (3), pp. 5060.

STANLEY, L.L. \& WiSNER, J.D. (2001) Service quality along the supply chain: implications for purchasing, Journal of Operations Management, 19, (3), pp. 287-306.

STANLEY, L.L. \& WISNER, J.D. (2002) The determinants of service quality: issues for purchasing, European Journal of Purchasing and Supply Management, 8, (2), pp. 97-109.

StUART, F.I. \& MUELlER, P.J.R. (1994) Total quality management and supplier partnerships: a case study, International Journal of Purchasing and Materials Management, 30, (1), pp. $14-20$.

Tan, K.C., Kannan, V.R., Handfield, R.B \& GHosh, S. (1999) Supply chain management: an empirical study of its impact on performance, International Journal of Operations and Production Management, 19, (10), pp. 1034-1052.

TRACEY, M. (1998) The importance of logistics efficiency to customer service and firm performance, International Journal of Logistics Management, 9, (2), pp. 65-80.

TEAS, R.K. (1994) Expectations as a comparison standard in measuring service quality: an assessment of a reassessment, Journal of Marketing, 58, (1), pp. 132-139.

TRENT, R.J. \& MonczKA, R.M. (1999) Achieving world-class supplier quality, Total Quality Management, 10, (6), pp. 927-938.

VonderembSe, M.A. \& TRACEY M. (1999) The impact of supplier selection criteria and supplier involvement on manufacturing performance, The Journal of Supply Chain Management, August, pp. 33-39.

WATTS, C.A. \& HAHN, C.K. (1993) Supplier development programs: an empirical analysis, International Journal of Purchasing and Materials Management, April, pp. 11-17.

Williams, A.R.T., DAle, B.G., \& VAN DER Wiele, T. (1999) Total quality: the resilence factor, Journal of Business Performance, 3, (2), pp. 22-30. 
WISNER, J. \& StANLEY, L.L. (1999) Internal relationships and activities associated with high levels of purchasing service quality, The Journal of Supply Chain Management, 35, (3), pp. 25-31.

Wynstra, F., Weggeman, M. \& VAn Weele, A. (2003) Exploring purchasing integration in product development, Industrial Marketing Management, 32, (1), pp. 69-83.

Young, J.A. \& VARBLE, D.L. (1997) Purchasing's performance as seen by its internal customers: a study in a service organization, International Journal of Purchasing and Materials Management, 33, (3), pp. 36-41. 
Table I Constructs Pertaining to Quality Management Purchasing

Table II Comparisons Between Respondents and Non-Respondents (Duns \& Bradstreet Database)

Table III Respondents' Industries as Reported in the Sample

Table IV Measures and Summary Statistics

Table V Summary of CFA Fit Indexes

Table VI Assessment of Discriminant Validity

Figure 1 Theoretical Framework

Figure 2 Theoretical Framework in LISREL Representation

Figure 3 Results from the Structural Model Analysis 
Table I. Constructs Pertaining to Quality Management Purchasing

\begin{tabular}{|c|c|c|}
\hline Action program & Description & Selected literature \\
\hline Supplier Qualit & yEstablishment of cooperative & Ahire et al. (1996), Anderson et al. (1994), \\
\hline lanagement & $\begin{array}{l}\text { relationships with suppliers and } \\
\text { enhancement of suppliers' } \\
\text { capabilities to meet the buyer's } \\
\text { requirements }\end{array}$ & $\begin{array}{l}\text { Black \& Porter (1996), Caddick \& Dale } \\
\text { (1998), Carter \& Narasimhan (1994), Carter } \\
\text { et al. (1998), Dale (1999), Flynn et al. } \\
\text { (1994), Lascelles \& Dale (1989), Powell } \\
\text { (1995), Saraph et al. (1989), Trent \& } \\
\text { Monczka (1999), Williams et al. (1999) }\end{array}$ \\
\hline $\begin{array}{l}\text { Personnel } \\
\text { Management }\end{array}$ & $\begin{array}{l}\text { Management of employees based } \\
\text { on empowerment, training, } \\
\text { teamwork, performance } \\
\text { evaluation, and reward and } \\
\text { recognition }\end{array}$ & $\begin{array}{l}\text { Ahire et al. (1996), Black \& Porter (1996), } \\
\text { Carter \& Narasimhan (1994), Carter et al. } \\
\text { (1998), Carter et al. (2000), Curkovic et al. } \\
\text { (2000), Flynn et al. (1994), Giunipero \& } \\
\text { Vogt (1997), Narasimhan et al. (2001) } \\
\text { Powell (1995), Saraph et al. (1989) }\end{array}$ \\
\hline $\begin{array}{l}\text { Cross-Functior } \\
\text { Coordination }\end{array}$ & $\begin{array}{l}1 \text { Coordination with other functiona } \\
\text { areas in the company to improve } \\
\text { quality }\end{array}$ & $\begin{array}{l}1 \text { Anderson et al. (1994), Burt (1989), Carter } \\
\text { \& Narasimhan (1994), Carter et al. (1998), } \\
\text { Dowlatshahi (1998), Giunipero \& Vogt } \\
\text { (1997), Wynstra et al. (2003) }\end{array}$ \\
\hline $\begin{array}{l}\text { Quality } \\
\text { Information }\end{array}$ & $\begin{array}{l}\text { Effective evaluation and } \\
\text { monitoring of customer } \\
\text { satisfaction levels, purchasing, anc } \\
\text { supplier quality performance }\end{array}$ & $\begin{array}{l}\text { Ahire et al. (1996), Black \& Porter (1996); } \\
\text { Flynn et al. (1994), Powell (1995), Saraph et } \\
\text { al. (1989), Lascelles \& Dale (1989) }\end{array}$ \\
\hline $\begin{array}{l}\text { Management } \\
\text { Commitment }\end{array}$ & $\begin{array}{l}\text { Purchasing management } \\
\text { committed to total quality }\end{array}$ & $\begin{array}{l}\text { Ahire et al. (1996), Anderson et al. (1994); } \\
\text { Black \& Porter (1996), Caddick \& Dale } \\
\text { (1998), Carter et al. (1998), Curkovic et al. } \\
\text { (2000); Flynn et al. (1994), Powell (1995), } \\
\text { Saraph et al. (1989) }\end{array}$ \\
\hline Benchmarking & $\begin{array}{l}\text { Evaluation and improvement of } \\
\text { the company's purchasing process } \\
\text { and performance by analyzing } \\
\text { other organizations' purchasing } \\
\text { process and performance }\end{array}$ & $\begin{array}{l}\text { Ahire et al. (1996), Black \& Porter (1996); } \\
\text { Camp (1989), Carr \& Smeltzer (1999), } \\
\text { Powell (1995), Hackman \& Wageman } \\
(1995)\end{array}$ \\
\hline
\end{tabular}


Table II. Comparisons Between Respondents and Non-Respondents (Duns \& Bradstreet Database)

\begin{tabular}{llcccc}
\hline & & $\mathrm{n}$ & Mean & Standard Deviation & Significance \\
\hline Sales (million Euros $€$ ) & Non-Respondents & 898 & 169.38 & 514.11 & 0.383 \\
& Respondents & 302 & 141.61 & 349.83 & \\
\hline Number of employees & Non-Respondents & 890 & 536 & 1,024 & 0.637 \\
& Respondents & 302 & 568 & 932 & \\
\hline
\end{tabular}


Table III. Respondents' Industries as Reported in the Sample

\begin{tabular}{lc} 
Industry & $\begin{array}{c}\text { Percentage } \\
\text { of } \\
\text { respondents }\end{array}$ \\
\hline Food and beverage & $18.9 \%$ \\
Auto components & $15.0 \%$ \\
Miscellaneous manufacturing & $13.4 \%$ \\
Chemicals & $12.4 \%$ \\
Machinery & $6.5 \%$ \\
Pharmaceutical products & $4.9 \%$ \\
Construction materials & $4.6 \%$ \\
Telecommunications \& electronic equipment & $3.9 \%$ \\
Electricity materials & $3.9 \%$ \\
Primary metals & $3.9 \%$ \\
Paper & $3.6 \%$ \\
Electric appliances & $3.3 \%$ \\
Non ferrous metallurgy & $2.9 \%$ \\
Textile & $2.9 \%$ \\
Total & $100.0 \%$ \\
\hline
\end{tabular}




\begin{tabular}{|c|c|c|c|c|}
\hline & & & & Reliabilit \\
\hline Code & Construct / Item & Mean & SD & $\mathrm{y}$ \\
\hline QMP & QUALITY MANAGEMENT PURCHASING & 3.47 & 0.52 & 0.75 \\
\hline SQM & Supplier Quality Management & 3.07 & 0.73 & 0.76 \\
\hline V1 & Certification of suppliers under ISO 9000 & 3.64 & 0.96 & \\
\hline $\mathrm{V} 2$ & Supplier evaluation & 3.62 & 1.11 & \\
\hline V3 & Supplier reward and recognition & 2.96 & 1.26 & \\
\hline V4 & Training for suppliers & 2.04 & 1.08 & \\
\hline V5 & Supply base rationalization & 3.64 & 1.31 & \\
\hline V6 & Supplier's sharing of internal information & 2.55 & 1.21 & \\
\hline V7 & Supplier involvement in the buyer's product design process & 3.01 & 1.24 & \\
\hline PM & Personnel management & 3.57 & 0.71 & 0.75 \\
\hline V8 & Job autonomy & 3.85 & 0.88 & \\
\hline V9 & Job security & 3.06 & 1.26 & \\
\hline V10 & Involvement in decisions & 3.70 & 1.01 & \\
\hline V11 & Training & 3.78 & 0.93 & \\
\hline V12 & Teamwork & 3.49 & 1.05 & \\
\hline V13 & Reward and recognition & 3.58 & 1.23 & \\
\hline CFC & Cross-Functional Coordination & 3.57 & 0.90 & 0.69 \\
\hline V14 & Purchasing's interaction with quality & 3.89 & 1.09 & \\
\hline V15 & Purchasing's interaction with production & 3.78 & 1.07 & \\
\hline V16 & Purchasing's interaction with new product development & 2.99 & 1.30 & \\
\hline QI & Quality information & 4.01 & 0.86 & 0.82 \\
\hline V17 & Collection of quality performance information & 4.06 & 0.98 & \\
\hline V18 & Reporting of quality information to purchasing & 4.09 & 0.96 & \\
\hline V19 & Reporting of quality information to suppliers & 3.88 & 1.07 & \\
\hline $\mathrm{MC}$ & Management commitment & 3.69 & 0.79 & 0.71 \\
\hline V20 & Predominance of quality over other purchasing objectives & 3.95 & 0.97 & \\
\hline V21 & Purchasing management's evaluation based on quality & 3.30 & 1.12 & \\
\hline V22 & Predominance of quality in supplier selection and evaluation & 3.80 & 0.89 & \\
\hline BK & Benchmarking & 2.92 & 0.86 & 0.72 \\
\hline V23 & Formal procedure for benchmarking & 3.51 & 1.06 & \\
\hline V24 & Benchmarking the purchasing process & 3.11 & 1.12 & \\
\hline $\mathrm{V} 25$ & Benchmarking purchasing performance & 2.15 & 1.06 & \\
\hline $\mathrm{OP}$ & OPERATIONAL PERFORMANCE & 3.70 & 0.62 & 0.68 \\
\hline V26 & Quality & 3.31 & 1.01 & \\
\hline V27 & Delivery & 4.34 & 0.63 & \\
\hline V28 & Inventory & 3.34 & 0.97 & \\
\hline V29 & Cost & 3.78 & 0.86 & \\
\hline SQ & INTERNAL CUSTOMER SATISFACTION & 3.88 & 0.63 & 0.69 \\
\hline V30 & Reliability & 3.70 & 1.01 & \\
\hline V31 & Empathy & 3.89 & 0.79 & \\
\hline V32 & Assurance & 3.98 & 1.04 & \\
\hline V33 & Responsiveness & 3.94 & 0.76 & \\
\hline$*$ & Tangibles & 4.53 & 0.88 & \\
\hline
\end{tabular}

*Item dropped during validity and reliability analyses 
Table V. Summary of CFA Fit Indexes Constructs/ Construct's pair

\begin{tabular}{lcccccccc} 
Fit Measures & $\begin{array}{c}\text { Recommended } \\
\text { threshold values }\end{array}$ & SQM & PM & MC-BK & CO-IN & QMP & OP & SQ \\
\hline$\chi^{2}$ & & 23.63 & 16.64 & 7.72 & 6.50 & 16.66 & 1.69 & 2.01 \\
$p$ - value & $\geq 0.05$ & 0.05 & 0.05 & 0.46 & 0.59 & 0.05 & 0.43 & 0.37 \\
d.f. & & 14 & 9 & 8 & 8 & 9 & 2 & 2 \\
$\chi^{2} /$ d.f. & $\leq 3.00$ & 1.69 & 1.85 & 0.96 & 0.81 & 1.85 & 0.84 & 1.00 \\
RMSEA & $\leq 0.10$ & 0.05 & 0.05 & 0.00 & 0.00 & 0.05 & 0.00 & 0.00 \\
RMSR & $\leq 0.10$ & 0.04 & 0.04 & 0.03 & 0.02 & 0.04 & 0.01 & 0.02 \\
NNFI & $\geq 0.90$ & 0.97 & 0.97 & 1 & 1 & 0.96 & 1 & 1 \\
CFI & $\geq 0.90$ & 0.98 & 0.98 & 1 & 1 & 0.98 & 1 & 1 \\
GFI & $\geq 0.90$ & 0.98 & 0.98 & 0.99 & 0.99 & 0.98 & 1 & 1 \\
AGFI & $\geq 0.90$ & 0.96 & 0.96 & 0.98 & 0.98 & 0.96 & 0.99 & 0.98 \\
\hline
\end{tabular}


Table VI. Assessment of Discriminant Validity

\begin{tabular}{|c|c|c|c|c|c|}
\hline & \multicolumn{5}{|c|}{ Chi-Square statistic } \\
\hline & & Unconstrained & Constrained & & \\
\hline & Correlations & model (d.f.) & model (d.f.) & Difference & $p$-value \\
\hline \multicolumn{6}{|l|}{ Supplier quality management with } \\
\hline Personnel management & $0.63 *$ & $90.40(64)$ & $264.70(65)$ & 174.30 & 0.00 \\
\hline Cross-functional coordination & $0.36^{*}$ & $97.00(34)$ & $212.78(35)$ & 115.78 & 0.00 \\
\hline Quality information & $0.51 *$ & $47.21(34)$ & $346.98(35)$ & 299.77 & 0.00 \\
\hline Management commitment & $0.35 *$ & $59.20(34)$ & $225.68(35)$ & 166.48 & 0.00 \\
\hline Benchmarking & $0.45^{*}$ & $56.85(34)$ & $206.40(35)$ & 149.55 & 0.00 \\
\hline \multicolumn{6}{|l|}{ Personnel management with } \\
\hline Cross-functional coordination & $0.50 *$ & $41.90(26)$ & $143.93(27)$ & 102.03 & 0.00 \\
\hline Quality information & $0.49 *$ & $57.67(26)$ & $346.39(27)$ & 288.74 & 0.00 \\
\hline Management commitment & $0.55^{*}$ & $39.21(26)$ & $147.18(27)$ & 107.97 & 0.00 \\
\hline Benchmarking & $0.51 *$ & $52.65(26)$ & $191.69(27)$ & 139.04 & 0.00 \\
\hline \multicolumn{6}{|c|}{ Cross-functional coordination with } \\
\hline Quality information & $0.26^{*}$ & $6.50(8)$ & $151.25(9)$ & 144.77 & 0.00 \\
\hline Management commitment & $0.46^{*}$ & $20.22(8)$ & $123.09(9)$ & 102.87 & 0.00 \\
\hline Benchmarking & $0.35^{*}$ & $23.95(8)$ & $151.79(9)$ & 127.84 & 0.00 \\
\hline \multicolumn{6}{|l|}{ Quality Information with } \\
\hline Management commitment & $0.28 *$ & $18.54(8)$ & $175.93(9)$ & 157.39 & 0.00 \\
\hline Benchmarking & $0.31 *$ & $9.07(8)$ & $175.96(9)$ & 166.89 & 0.00 \\
\hline \multicolumn{6}{|l|}{ Management commitment with } \\
\hline Benchmarking & $0.17^{*}$ & $7.72(8)$ & $179.26(9)$ & 171.54 & 0.00 \\
\hline \multicolumn{6}{|l|}{$\begin{array}{l}\text { Quality Management Purchasing } \\
\text { with }\end{array}$} \\
\hline Operational Performance & $0.47 *$ & $67.67(34)$ & $203.04(35)$ & 135.37 & 0.00 \\
\hline Internal Customer Satisfaction & $0.49 *$ & $44.73(34)$ & $206.55(35)$ & 161.82 & 0.00 \\
\hline \multicolumn{6}{|l|}{ Operational Performance with } \\
\hline Internal Customer Satisfaction & $0.73 *$ & $23.56(19)$ & $71.33(20)$ & 47.77 & 0.00 \\
\hline
\end{tabular}

* Correlation is significant at the 0.05 level (2-tailed) 
Figure 1. Theoretical Framework

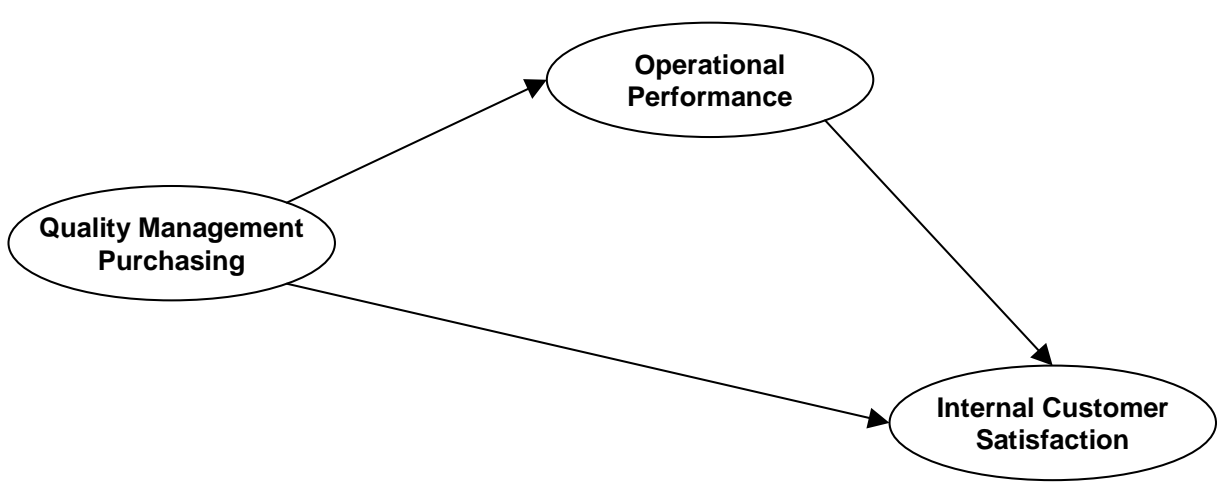


Figure 2. Theoretical Framework in LISREL Representation

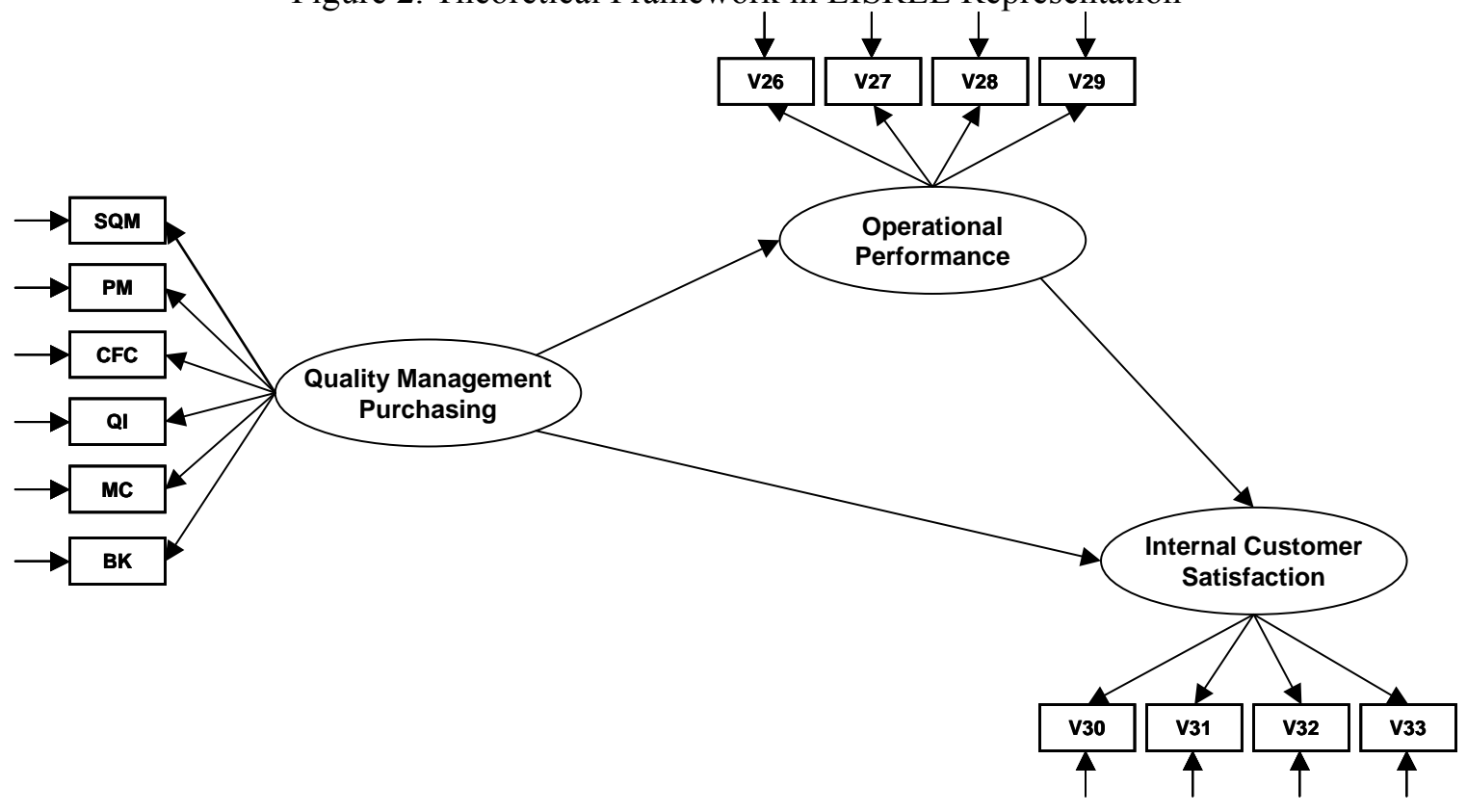


Figure 3. Results from the Structural Model Analysis

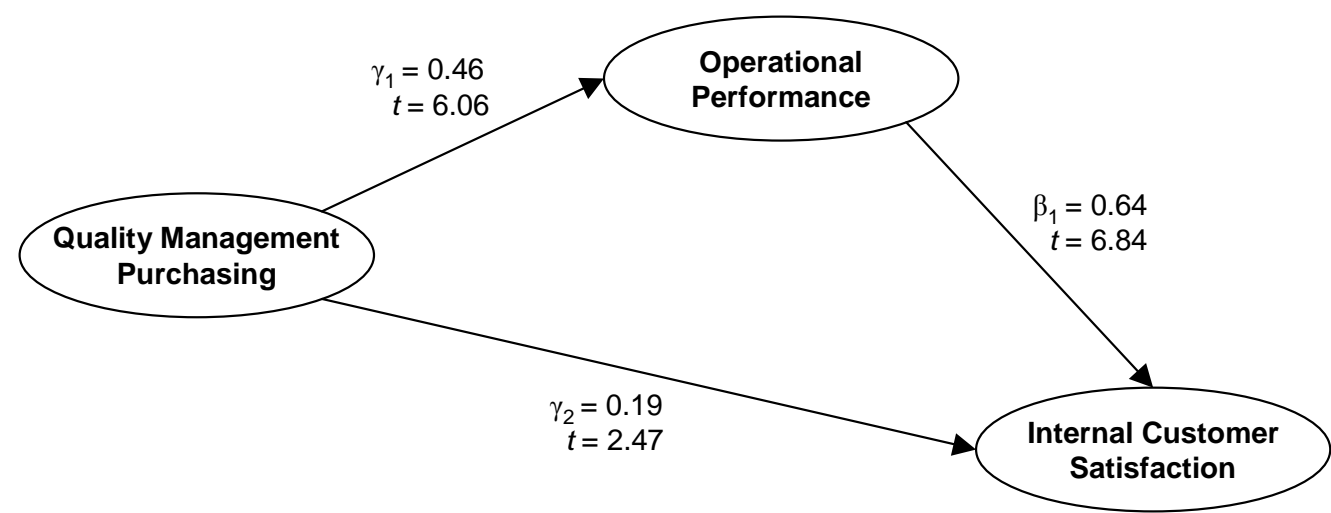

